\title{
MANUFACTURE OF NOVEL PRODUCTS USING GREEN TEA
}

By

NANDUNI HEMANTHIE WICKRAMATUNGA

Thesis submitted to the University of Sri Jayawardenapura for the award of the degree of Masters of Food Science and Technology on 2006. 


\section{Declaration}

The work described in this thesis was carried out by me under the supervision of Prof. A. Bamunuarachchi and a report on this thesis has not been submitted in whole or in part of any University or any other institution for another degree.

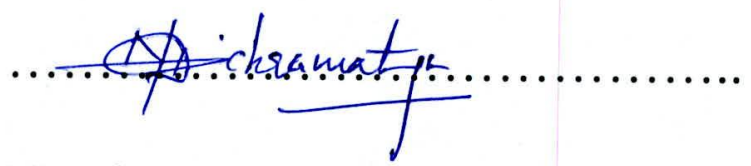

Nanduni H. Wickramatunga 
I certify that the above statement made by the candidate is true and that this thesis is suitable for submission to the University for the purpose of evaluation.

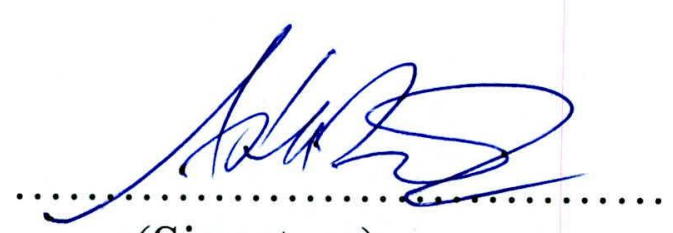

(Signature)

Prof... A Bamunuarachchi..

(Supervisor/s Name)

Profensor. of Chemistry

Facutty... of .......pplied Sciences

Dept of oood Science \& Technology (Supervisor/s Address) 


\section{TABLE OF CONTENTS}

Page

Table of content $\quad$ i

List of Tables $\quad \mathrm{v}$

List of Figures vi

Acknowledgement vii

Abstract viii

CHAPTER 1 - INTRODUCTION 1

CHAPTER 2 - LITERATURE REVIEW 3

2.1 General 3

2.2 Composition of tea flush 4

2.3 The main chemical constituents of tea $\quad 5$

2.3.1Polyphenol $\quad 5$

$\begin{array}{ll}\text { 2.3.2 Catechins } & 6\end{array}$

$\begin{array}{ll}\text { 2.3.3 Other Polyphenols } & 8\end{array}$

2.3.4 Amino acids 99

2.3.5 Caffeine and other Xanthines 9

$\begin{array}{ll}\text { 2.3.6 Carotenoids } & 10\end{array}$

$\begin{array}{ll}2.3 .7 \text { Volatiles } & 10\end{array}$

$\begin{array}{ll}\text { 2.3.8 Lipids } & 10\end{array}$

$\begin{array}{ll}2.3 .9 \text { Enzymes } & 10\end{array}$ 
2.4 Tea manufacture

2.4.1Chemistry of oxidation (Fermentation)

2.4.1.1 Catechin oxidation

2.4.1.2 Theaflavins

2.5 Green Tea Processing

2.5.1 Enzyme inactivation

2.5.2 Rolling 16

2.5.3 Shaping up

2.5.4 Drying

2.6 Benefits of Green Tea

2.6.1 EGCG is a potent antioxidant

2.6.2 Special Benefits of Green Tea

2.6.3 Green Tea and Weight Loss $\quad 21$

2.7 Green tea as a soft drink

\section{CHAPTER 3 EXPERIMENTAL}

3.1 Use of fresh tea leaves to manufacture green tea extract

3.2 Use of processed tea leaves to manufacture green tea extract

3.3 Manufacture of flavoured green tea extract

3.4 Preserving fresh tea leaves for further use by dipping in Brine solution

3.5 Preserving fresh tea leaves by blast freezing 
3.7.1 Green tea extract

3.7.1.1 Determination of colour

3.7.1.2 Determination of $\mathrm{pH}$

3.7.1.3 Keeping quality by Total plate count

3.7.1.4 Sensory analysis of Green tea extract

3.7.1.5 Sensory analysis of Green tea jelly

3.7.1.6 Analysis of Polyphenols

\section{CHAPTER 4 RESULTS AND DISCUSSION}

4.1 Use of fresh tea leaves to manufacture green tea extract

4.2 Use of processed tea leaves to manufacture green tea extract 30

4.3 Manufacture of flavoured green tea extract $\quad 30$

4.4 Preserving fresh tea leaves for further use

by dipping in Brine solution

4.5 Preserving fresh tea leaves by blast freezing

4.6 Manufacture of Green tea jelly using the extract

4.7 Analysis of the above products

4.7.1 Green tea extract

4.7.1.1 Determination of colour

4.7.1.2 Determination of $\mathrm{pH}$

4.7.1.3 Keeping Quality of Green tea extract 
4.7.1.5 Sensory analysis of Green tea jelly

4.7.1.6 Analysis of Polyphenols

CONCLUSION

38

REERENCES

APPENDIX I

41

APPENDIX II

42 


\section{LIST OF TABLES}

Table 1: Composition of tea flush

Table 2: Polyhenolic compounds in fresh tea leaf

Table 3: Characteristics of Catechin

Table 4: An overview of the basic processing methods for various green teas

Table 5: Absorbance spectrum data to select wave length for green tea extract

Table 6: Absorbance of green tea extract of wave length $400 \mathrm{~nm}$

Table 7: $\mathrm{pH}$ of green tea extract

Table 8: Results of sensory evaluation of Green tea extract

Table 9: Results of sensory evaluation of Green tea jelly 


\section{LIST OF FIGURES}

Fig. 1: Chemical structure and types of Catechin

Fig. 2: Other Polyphenols in tea 8

Fig. 3: Theanine 9

Fig. 4: The Methylxanthines

9

$\begin{array}{ll}\text { Fig. 5: Process flow diagram of manufacturing green tea } & 14\end{array}$

Fig. 6: Colour absorbance Green tea

Fig. 7: Colour variation in Green tea extract

Fig. 8: Variation of $\mathrm{pH}$ of Green tea extract

Fig. 9: Sensory evaluation of Green tea extracts

Fig. 10: Sensory Evaluation of Green tea jelly 


\section{ACKNOWLEDGEMENT}

First and foremost I wish to express my deepest gratitude to my project supervisor Prof.Arthur Bamunuarachchi for his valuable advice, encouragement and guidance for paying his maximum attention in the preparation of this report.

I wish to express my sincere thanks to Dr. K.K.D.S. Ranaweera, Co-ordinator Food Science and Technology Programme, University of Sri Jayawardenapura and all the academic and non-academic staff of the department for their assistance and support during this study and for providing me the opportunity to carry out this study in this Department. Thanks also extended to the Paradise Farm Ltd. for supplying samples of Organic Green tea for the study.

Special thanks to my husband for the assistance and moral support rendered throughout this study.

Finally I wish to thank all my friends and relatives who supported me in bringing this study to a successful completion. 


\title{
MANUFACTURE OF NOWEL PRODUCTS USING GREEN TEA
}

\section{By}

\section{NANDUNI HEMANTHIE WICKRAMATUNGA}

\begin{abstract}
Green tea is fast becoming popular in the world due to its health enhancing components. Green tea beverage is available in the market as different products. All the nutrients in green tea do not dissolve into liquid, so cannot be consumed in the beverage. The full effects of the leaves could be optimized by finding methods to consume green tea leaves.
\end{abstract}

The objective of this research was to improve the quality of bottled green tea by adding flavour and developing a jelly using the bottled tea extract and to find ways to preserve green tea leaves for future leaves.

The study showed that the green tea extracts bottled without preservatives had good keeping quality and that there is a possibility of preserving green tea leaves in Brine solutions. Sensory studies showed addition of flavour improves the acceptability of green tea beverage and the sweetened Green tea jelly was more preferred. The overall study showed the possibility of manufacturing value added green tea products that could have an appeal to the average consumer. 


\section{CHAPTER 1}

\section{INTRODUCTION}

Green tea is considered to be "the virgin of tea's", as it is the youngest, freshest and the least processed tea. Green tea has been receiving much attention lately due to its pharmacological effects. Substances in green tea help to maintain good health and are potentially effective in preventing cancer, heart diseases and even cure food poisoning. It also provides the human body with numerous health enhancing components such as Catechins, Polyphenols, Flavonoids, Vitamin B complex, Vitamin C, Vitamin E and Fluoride in its natural state.

Tea is fast becoming a major player in the beverage market. Nowadays, most people prefer ready to serve (RTS) drinks due to their busy schedules. There are a range of fruit flavoured black teas in the market which can be considered as soft drinks. Green tea as a soft drink has the advantage of having a healthy image, as the beverage is lower in sweetness. The green tea flavour blends well with citrus, pineapple and ginger flavours, making it more suitable for a soft drink.

However, green tea in liquid form does not optimize the full effects of the leaves, because all useful substances do not dissolve into liquid. But this problem can be solved by finding tasty ways to "eat green tea." All the nutrition in green tea can be consumed by using tea leaves fresh or using them to manufacture many products that are available in the market. 
The thesis briefly presents the small scale experiments carried out to ascertain the possibility of making an acceptable bottled green tea, fresh tea leaves and the products made from green tea extracts. 


\section{CHAPTER 2}

\section{LITERATURE REVIEW}

\subsection{General}

Tea is made from the young leaves and unopened buds of the tea plant Camellia sinensis. Tea is classified into three categories depending on the manufacturing process. They are non fermented, semi-fermented and fermented types. Non fermented tea is made by stopping the functions of flavoprotein in tea leaves. Green tea is a type of non-fermented tea. Oolong tea is a typical semi-fermented tea which allows flavoproteins to work to a certain extent. Black tea is the fermented tea that optimizes the function of flavoproteins to the fullest.

The tea infusion has little food value, containing four calories per cup (Pintauro, Nicholas, Park Riclye N.J. 1970). The fresh tea leaf is rich in vitamin C, but it would be destroyed during tea manufacture.

The younger the tea leaves, the better the tea quality. The white-haired bud and the two adjacent youngest leaves (tea flush) are plucked, but plucking of longer shoots containing three or even four to six leaves is not uncommon.

Final product characters depend on the unusual chemical composition of the fresh leaf. The group of polyphenols give tea infusion its briskness, strength and colour. They are also responsible for the characteristic taste of tea. ((Pintauro, Nicholas, Park Riclye N.J. 1970). 


\subsection{Composition of tea flush}

\begin{tabular}{|l|c|}
\hline \multicolumn{1}{|c|}{ Compounds } & \% dry weight \\
\hline Protein & 15 \\
Amino acids & 04 \\
Polysaccharides & 14 \\
Monosaccharides & 04 \\
Lipids & 02 \\
Flavanols & 25 \\
Flavanols and Flavanol glycosides & 03 \\
Polyphenolic acids & 05 \\
Other polyphenols & 03 \\
Caffeine & 03 \\
Theobromine and Theophylline & 0.2 \\
Organic acids & 0.5 \\
Chllulose & 0.1 \\
\hline
\end{tabular}

Table 1 : Composition of tea flush 